\title{
The Effect of Retinoids on the Migration of Tenon's Capsule Fibroblasts
}

\author{
J. P. JOSEPH ${ }^{1}$, I. GRIERSON ${ }^{1}$ AND R.A. HITCHINGS ${ }^{2}$
}

London

\begin{abstract}
Summary
The effect of the retinoids, retinol and all-trans acid, was assessed in vitro on the migration of rabbit Tenon's capsule fibroblasts, with a view to using these drugs as inhibitors of fibrosis in relation to trabeculectomies. No inhibition of fibroblast migration was demonstrated, and in fact retinol significantly enhanced both the random and directed migration of these cells $(\mathbf{p}<0.001$ and $\mathbf{p}<0.01$, respectively). This study emphasises the importance of using appropriate cells when investigating the effects of drugs on wound healing.
\end{abstract}

Fibrosis at the operation site is the most common cause of the failure of trabeculectomies. ${ }^{1,2,3}$ The migration of fibroblasts from the surrounding connective tissues to the wound site has been demonstrated to contribute towards the scarring process. ${ }^{4,5}$ Retinoids have been shown to inhibit the migration of embryonic human skin fibroblasts. ${ }^{6}$ There is also evidence that they inhibit collagen production and proliferation of embryonic and adult human skin fibroblasts and of chick tendon fibroblasts. ${ }^{6}$ Retinoic acid has, in addition, been demonstrated to have potent effects in reversing squamous metaplasia in keratinising conditions of the conjunctiva. 7,8 This group of drugs seemed likely to have properties that would inhibit wound healing in relation to trabeculectomies. We have therefore investigated the effects of the retinoids, retinol (vitamin A) and retinoic acid, as inhibitors of Tenon's capsule fibroblast migration.

Material and Methods.

Fibroblasts. The technique of growing these cells has previously been described. ${ }^{9}$ Rabbit Tenon's capsule fibroblasts were grown in F10 medium with $10 \%$ new born calf serum, $100 \mathrm{units} / \mathrm{ml}$ of penicillin, $100 \mathrm{ug} / \mathrm{ml}$ of streptomycin, and 0.25 units $/ \mathrm{ml}$ of amphotericin B (Gibco, Paisley, Scotland). The cultures were maintained at $37^{\circ} \mathrm{C}$ in an atmosphere of $5 \% \mathrm{CO}_{2} / 95 \%$ air and were fed twice weekly. The cells were passaged at split ratios varying from $1-4$ to $1-10$ and were used between passages 2 to 5 in the experiments.

Fibronectin. Bovine fibronectin (Sigma, Poole, Dorset) was diluted with distilled water and stored at $-20^{\circ} \mathrm{C}$. We have previously demonstrated that $20 \mathrm{ug} / \mathrm{ml}$ of fibronectin is the optimal chemoattractant dose for rabbit Tenon's fibroblasts. ${ }^{9}$ This dose of fibronectin was therefore used as a chemoattractant in all the experiments. In addition, serum free F10 medium was run as a negative control.

Chemotaxis. Chemotaxis was undertaken in 48-well micro-chemotaxis chambers (Neuro Probe, Cabin John, Maryland) using a technique described in detail elsewhere ${ }^{9}$, and

Correspondence to: Dr. Ian Grierson, Pathology Department, The Institute of Ophthalmology, 17-25 Cayton Street, London EC1V 9AT

From: ${ }^{1}$ The Institute of Ophthalmology, London, and ${ }^{2}$ Moorfields Eye Hospital, London.

Presented, in part, at the Annual Congress of the Ophthalmological Society of the United Kingdom, April 1988. 
based on the original Boyden chamber. ${ }^{10}$ The cells are placed in the upper wells of the apparatus and are separated from the chemoattractant, which is placed in the lower wells, by a porous membrane. The upper wells of the apparatus have a volume of $50 \mu \mathrm{l}$; the lower wells $25 \mu \mathrm{l}$. The membrane is a sheet of polycarbonate $25 \times 80 \mathrm{~mm}, 10 \mu \mathrm{m}$ thick, and with pores $8 \mu \mathrm{m}$ in diameter bored through it (Nucleopore, Pleasanton, California). A single membrane is used to separate all 48 upper wells from the lower wells. Membranes contain the wetting agent polyvinylpyrrolidine and require treatment with gelatin in order to allow the adherence of fibroblasts with a normal morphology. ${ }^{11}$ Cells in the upper wells adhere to the upper surface of the membrane. They are then able to migrate through the pores in the membrane in response to chemoattractants in the lower wells, and stick to the distal surface of the membrane. The chemotaxis chambers were incubated at $37^{\circ} \mathrm{C}$ in $5 \% \mathrm{CO}_{2} / 95 \%$ air for 4 hours, whereupon the membranes were removed, fixed in ethanol for 30 seconds, air dried and stained with haematoxylin. Cells that had successfully migrated through the pores were counted on the distal surface of the membrane in 20 fields at $1000 x$ magnification (Olympus, Tokyo, Japan). The numbers of cells that had migrated indicated both the potency of the chemoattractant as well as the capability of the cells to migrate.

Retinoids. Retinol (vitamin A) and all trans retinoic acid (Sigma) were diluted with ANALAR grade ethanol to a $0.5 \mathrm{M}$ solution, aliquotted, and stored under liquid nitrogen at $-196^{\circ} \mathrm{C}$. All manipulations of the drugs were carried out in near darkness since the retinoids are light sensitive. Further dilutions were made with F10 medium with $10 \%$ new born calf serum. Medium containing the retinoids was sterilised by passage through a $0.22 \mu \mathrm{m}$ filter before addition to the cells.

A confluent culture of fibroblasts was passaged at a split ratio of $1-6$. One day later the medium was decanted and each flask was fed with a different concentration of retinoid, in near darkness and incubated for three days. ${ }^{6}$ Cells were detached from their flasks by exposure to $0.25 \%$ trypsin and $0.02 \%$ EDTA for three minutes. The fibrob- lasts were suspended in $10 \mathrm{ml} \mathrm{F10} \mathrm{with} 10 \%$ new born calf serum and centrifuged at $300 \mathrm{~g}$ for 10 minutes. The cells were washed once in serum free F10 medium, counted with a Coulter counter (model ZF) and resuspended at a concentration of $7 \times 10^{5}$ cells per $\mathrm{ml}$ in serum free F10, for each concentration of retinoid. 35,000 pretreated cells were then added to each of the upper wells of the microchemotaxis chamber, without the addition of any further drug. Untreated cells and cells exposed to the ethanol diluent were used as controls.

\section{Results}

Retinol Pretreatment of rabbit Tenon's fibroblasts with retinol at concentrations varying from $10^{-12}$ to $10^{-4} \mathrm{M}$ significantly increased the background random migration of the cells $(p<0.001$ Student $t$ test $)$. The response is shown in Fig. 1a. In the absence of retinol there is a random migration of $4.2 \pm 0.8$ (mean \pm S.E.M.) cells per $201000 \mathrm{X}$ fields across the membrane in four hours. Pretreatment with $10^{-4} \mathrm{M}$ retinol, for example, increased the random migration to $34.8 \pm 3.0$ cells $(p<0.001$ Student $t$ test $)$. At $10^{-8}$ the random migration was $14.5 \pm 0.5$ cells, while at $10^{-12} \mathrm{M}$ this was increased to $30.5 \pm 1.4$ cells per $201000 \mathrm{X}$ fields.

When an optimal dose of $20 \mathrm{ug} / \mathrm{ml}$ fibronectin was used as the chemoattractant, the response was somewhat different (Fig. 1b). At $10^{-4} \mathrm{M}$, retinol a similar number of cells migrated as in the retinol free control. However, with progressively decreasing doses of retinol down to the minimum tested of $10^{-}$ ${ }^{12} \mathrm{M}$, there was a progressive increase in the number of cells migrating, so that $100.8 \pm$ cells per $201000 \mathrm{X}$ fields migrated when pretreated with $10^{-12} \mathrm{M}$ retinol, compared to $51 \pm 9.1$ cells in the absence of retinol $(\mathrm{p}<0.01$ Student $\mathrm{t}$ test $)$.

\section{Retinoic acid}

Pretreatment of the cells with retinoic acid caused a doubling in the background random migration at $10^{-5} \mathrm{M}(\mathrm{p}<0.01$ Student $\mathrm{t}$ test $)$. However, when fibronectin was used as the chemoattractant there was no effect on the migration of the fibroblasts over the range of concentrations tested from $10^{-13}$ to $10^{-5} \mathrm{M}$.

The diluent of ANALAR grade ethanol 

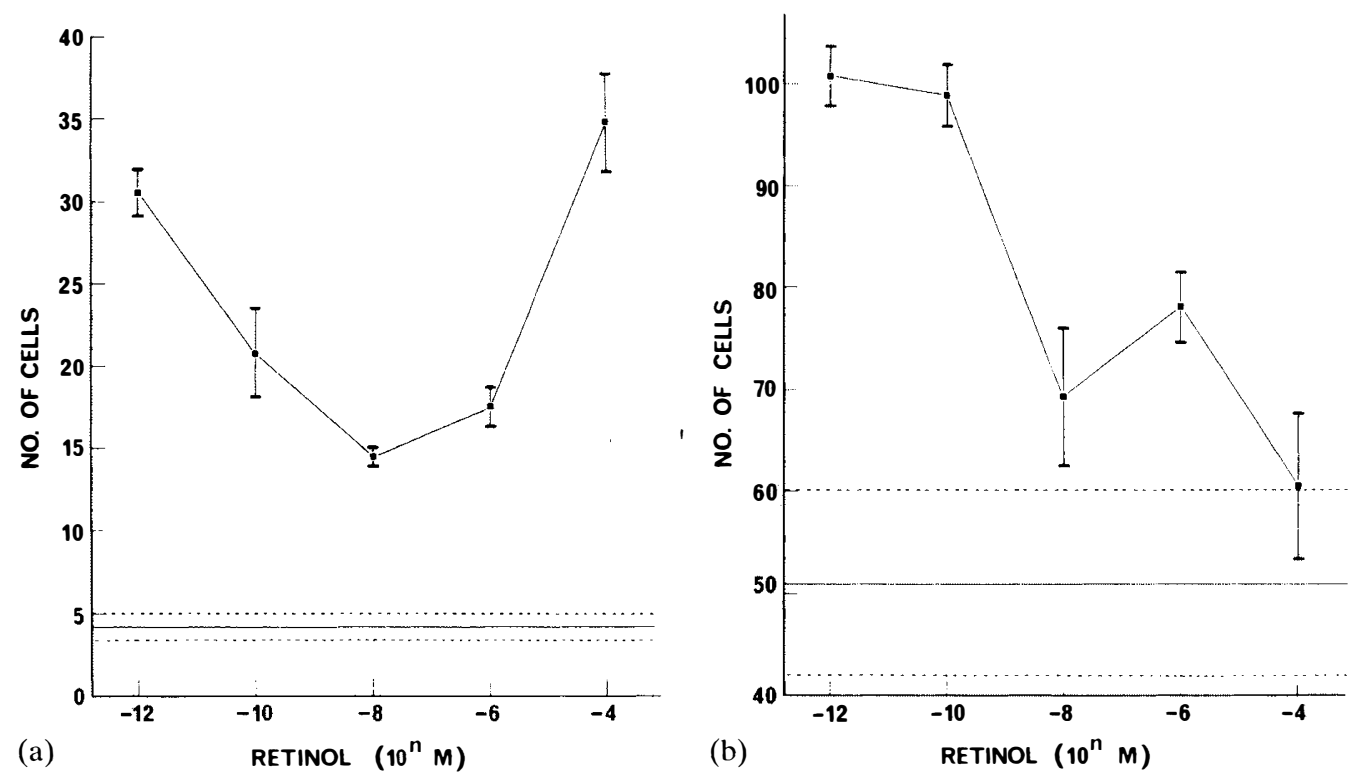

Fig.1 Graphs showing the effect of retinol on the migration of rabbit Tenon's fibroblasts. Cells have been pretreated for 24 hours with retinol. The solid horizontal line in each figure shows the migration of the untreated control cells, with the dashed lines showing the S.E.M. (a) shows the random migration of the cells in the absence of a chemoattractant. Random migration is significantly increased at all doses of retinol $(p<0.001$ Student t test). (b) Shows the response when $20 \mathrm{ug} / \mathrm{ml}$ fibronectin was used as the chemoattractant. Migration is significantly increased at $10^{-12}$ and $10^{-10} \mathrm{M}(p<0.01)$ and at $10^{-6} \mathrm{M}$ retinol $(p<0.05)$. Cells have been counted in 20 fields at 1000x magnification. For each point $n=4$; bars show the S. E.M.

constituted $0.02 \%$ of the solution at the strongest concentrations of retinoids tested. Even at a $2 \%$ concentration ethanol failed to affect the migration of the cells.

\section{Discussion}

Retinol enhances the migratory response of rabbit Tenon's fibroblasts, while retinoic acid is ineffective at inhibiting the chemoattractant effect of fibronectin for these cells. This result is contrary to the effect reported on human embryonic skin fibroblasts ${ }^{6}$ where retinol and several other retinoids at concentrations between $10^{-8}$ and $10^{-10} \mathrm{M}$ produced a marked decrease of the chemotactic response.

Retinoids have been shown to have pronounced effects on a wide variety of normal and neoplastic cells. ${ }^{12}$ The responses seen are diverse and are poorly understood but it is clear that different types of the same cell eg. fibroblasts, do not always respond in the same way to the same stimulus. Thus, it is not surprising that the fetal dermal fibroblasts used in the studies of Hein ${ }^{6}$ respond in a different way to the mature Tenon's capsule fibroblasts used in our study. Although we have used rabbit cells, we have previously demonstrated that rabbit and human ocular fibroblasts respond in an almost identical way to chemoattractants. ${ }^{13}$

Topical retinoic acid has been shown markedly to reduce squamous metaplasia and keratinisation of the conjunctiva. ${ }^{7,8}$ It has also been demonstrated to expedite healing of experimental corneal epithelial wounds when applied at a concentration of $3.3 \mathrm{x}$ $10^{-3} \mathrm{M}^{14} ;$ retinol however, was ineffective in this model.

In view of the diverse and variable effects of retinoids, it is obviously important to use appropriate cells, derived from the site at which healing is to be investigated, when studying the effects of these drugs. In spite of some evidence in the literature, our work suggests that topical retinoids would facilitate 
healing at the site of a trabeculectomy, which is opposite to the desired response, and we therefore do not intend to pursue the use of these drugs as adjuvant treatment to prevent bleb fibrosis.

This study was supported by the T.F.C. Frost Charitable Trust, the International Glaucoma Association, and a Moorfields Endowment Grant. Secretarial assistance was provided by Pat Goodwin.

\section{References}

${ }^{1}$ Maumenee AE:. External filtering operations for glaucoma: the mechanism of function and failure. Trans Am Ophthalmol Soc 1960, 58: 319-25.

2 Addicks EM, Quigley HA, Green R, Robin AL: Histologic characteristics of filtering blebs in glaucomatous eyes. Arch Ophthalmol 1983, 101: 795-8.

${ }^{3}$ Hitchings RA, Grierson I: Clinico pathological correlation in eyes with failed fistulising surgery. Trans Ophthalmol Soc UK 1983, 103: 84-8.

${ }^{4}$ Miller MH, Joseph NH, Ennis KW, Grierson I, Hitchings RA: An animal model of filtration surgery. Trans Ophthalmol Soc UK 1985, 104: 893-7.

${ }^{5}$ Dejardins DC, Parrish RK, Folberg R, Nevarez J, Heuer DK, Gressel MG: Wound healing after filtering surgery in owl monkeys. Arch Ophthalmol 1986, 104: 1835-9.
${ }^{6}$ Hein R, Mensing H, Muller PK, et al: Effect of vitamin $\mathrm{A}$ and its derivatives on collagen production and chemotactic response of fibroblasts. Br J Dermatol 1984, 111: 37-44.

${ }^{7}$ Wright P: Topical retinoic acid therapy for disorders of the outer eye. Trans Ophthalmol Soc UK 1985, 104: 869-74.

8 Tseng SCG. Topical retinoid treatment for dry eye disorders. Trans Ophthalmol Soc UK 1985, 104: 489-95.

9 Joseph JP, Grierson I, Hitchings RA: Normal rabbit aqueous humour, fibronectin, and fibroblast conditioned medium are chemoattractant to Tenon's capsule fibroblasts. Eye 1987, 1: 585-92.

${ }^{10}$ Boyden S: The chemotactic effect of mixtures of antibody and antigen on polymorphonuclear leucocytes. J Exp Med 1962, 115: 453-66.

11 Postlethwaite AE, Synderman R, Kang AH: The chemotactic attraction of human fibroblasts to a lymphocyte derived factor. $J$ Exp Med 1976, 144: 1188-203.

12 Lotan R: Effects of vitamin A and its analogues (retinoids) on normal and neoplastic cells. Biochim Biophys Acta 1980, 605: 33-91.

13 Joseph JP, Grierson I, Hitchings RA: Chemotactic activity of aqueous humour: a cause of failure of trabeculectomies? Arch Ophthal (In press).

14 Ubels JL, Edelhauser HF, Austin KH: Healing of experimental corneal wounds treated with topically applied retinoids. Am J Ophthalmol 1983, 95: 353-8. 